\title{
SEL1L wt Allele
}

National Cancer Institute

\section{Source}

National Cancer Institute. SEL1L wt Allele. NCI Thesaurus. Code C105008.

Human SEL1L wild-type allele is located in the vicinity of $14 \mathrm{q} 31$ and is approximately $62 \mathrm{~kb}$ in length. This allele, which encodes protein Sel-1 homolog 1 protein, plays a role in degradation of misfolded proteins. 